Takahiko Kamibayashi MD, Katsumi Harasawa MD, Mervyn Maze MB CHB MrCP

\section{Alpha-2 adrenergic agonists}

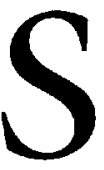
INCE the first reports on the utility of $\alpha_{2}$ adrenergic agonists, less than a decade ago, the clinical application of this class of compound continues to expand. Initially, reports concentrated on the anaesthetic-sparing actions of $\alpha_{2}$ adrenergic agonists. Now, their efficacy in pain management, regional anaesthesia, and organ protection are coming to the fore. Furthermore, there are a plethora of studies addressing the manner by which $\alpha_{2}$ agonists can enhance the safety of other anaesthetic agents, as well as suggestions on how to improve the therapeutic window of its own administration. Here, we have concentrated on clinical studies but have included a short section on interesting preclinical studies which may be extrapolated to the clinical arena.

Adrenergic receptors have been differentiated into $\alpha$ and $\beta$ based on the rank order of potency of various natural and synthetic catecholamines in different physiological preparations. ${ }^{1}$ Subsequently, the $\alpha$ adrenoceptors were separated into two subtypes, $\alpha_{2}$ and $\alpha_{1}$, depending on their sensitivity to the $\alpha_{2}$-selective antagonist yohimbine or the $\alpha_{1}$ selective antagonist prazosin. ${ }^{2}$ Activation of $\alpha_{1}$ adrenoceptors can functionally antagonize $\alpha_{2}$-mediated CNS responses so it is critical to use compounds with high selectivity for the $\alpha_{2}$ adrenoceptor.

\section{Applied pharmacology}

Clonidine, an imidazole compound, is a selecrive partial agonist for $\alpha_{2}$-adrenoceptors with a ratio of approximately 200:1 $\left(\alpha_{2}: \alpha_{1}\right)$. Clonidine is rapidly and almost completely absorbed after oral administration and reaches a peak plasma level within $60-90 \mathrm{~min}$ by this route. Clonidine can also be delivered via a time-release transdermal patch although it takes a minimum of two days for therapeutic levels to be achieved by this route. ${ }^{3}$ The elimination half-life of clonidine is between 8-12 hr with $\approx 50 \%$ of the drug being metabolized in the liver to inactive metabolites while the rest is excreted unchanged in the kidney. A single dose of $0.3 \mathrm{mg}$ clonidine has the same pharmacokinetic and pharmacodynamic profile whether administered $p o$ or $s l^{4}$ Therefore, the $s l$ route can be predictably used in fasting patients, those having difficulty swallowing, or those who are unable to absorb drugs through the gastrointestinal tract. Clonidine is now being used by the rectal route of administration in children with $95 \%$ bioavailability and unchanged pharmacokinetic variables. ${ }^{5}$

Medetomidine, 4(5)-[1-2,3-dimethylphenyl[ethyl] imidazole], is the prototype of the novel superselective $\alpha_{2}$ agonists. It is an order of magnitude more selective than clonidine and is a full agonist at this class of receptor. ${ }^{6}$ Medetomidine is extremely potent and is active at low nanomolar concentrations and has been widely used in veterinary practice in Europe. Since the $\mathrm{D}$-enantiomer of this racemate is the active ingredient, dexmedetomidine has been developed for clinical use. The pharmacokinetic profile is more favourable for perioperative use than is clonidine because of its much shorter half life of approximately two hours. ${ }^{7}$ Phase III studies with this compound are currently being conducted in North America, Europe and Japan to investigate its perioperative utility.

Some of the ligands have an imidazole ring which facilitates binding to nonadrenergic imidazole-preferring receptors ${ }^{8,9}$ as well as to the $\alpha_{2}$ adrenoceptor. The cardiovascular properties of $\alpha_{2}$ ligands may vary considerably depending on whether the imidazole-preferring receptor is also activated. ${ }^{10}$ Other imidazoline compounds which have been investigated for their $\alpha_{2}$ agonist properties include tizanidine ${ }^{11}$ and mivazerol. ${ }^{12}$

\section{Premedication}

Since sedation, anxiolysis and antisialogogue action are attractive attributes in a premedication agent, administration of $\alpha_{2}$ agonists suits this purpose well. Another benefit of $\alpha_{2}$ agonists for premedication is their ability to potentiate the anaesthetic action of other agents and to reduce anaesthetic requirements during surgery. This effect is universally observed regardless of the type of anaesthetic, intravenous, volatile or regional blockade. Conversely, requirements for neuromuscular blocking agents remain unaffected by pretreatment with $\alpha_{2}$ agonists. ${ }^{13}$

The successful application of $\alpha_{2}$ agonists to patients at the extremes of life is now established. ${ }^{14,15}$ The

From the Anesthesiology Service Veterans Affairs Palo Alto Health Care Services, Palo Alto, CA 94304; and Department of Anesthesia, Stanford University, Stanford, CA 94305. 
elderly patient population appears to be one that is most likely to benefit from the sympatholytic effects of the drug because of the prevalence of coronary artery disease and hypertension. ${ }^{16,17}$ In patients between 4-12 yr, the combination of $4 \mu \mathrm{g} \cdot \mathrm{kg}^{-1}$ clonidine and $30 \mu \mathrm{g} \cdot \mathrm{kg}^{-1}$ atropine orally, $105 \mathrm{~min}$ before coming to the $\mathrm{OR}$, was more effective than diazepam at promoting anxiolysis and sedation. ${ }^{15}$

Clonidine significantly attenuated the rapid increases in blood pressure and heart rate during the transition between low and high doses of desflurane ${ }^{18,19}$ Similarly, the sympathoexcitatory response to $1.0 \mathrm{mg} \cdot \mathrm{kg}^{-1} \mathrm{keta}-$ mine, $i v$, was attenuated by $5 \mu \mathrm{g} \cdot \mathrm{kg}^{-1}$ clonidine, $p o$, as evidenced by the smaller increment in blood pressure. ${ }^{20}$ Clonidine premedication also blunted hypertension, tachycardia as well as increments in plasma catecholamine concentrations during stepwise increase in isoflurane concentration by mask anaesthesia. ${ }^{21}$

Several recent studies have reported on the use of premedication dose of clonidine in patients with coronary artery disease. Clonidine, $5 \mu \mathrm{g} \cdot \mathrm{kg}^{-1}$ decreased intraoperative sufentanil use and lowered catecholamine response while maintaining haemodynamic stability in coronary artery bypass graft surgery. ${ }^{22}$ To determine whether the addition of clonidine to a standardized general anaesthetic could safely provide postoperative sympatholysis for patients with known or suspected coronary artery disease, Ellis and colleagues ${ }^{23}$ randomly allocated patients undergoing elective major noncardiac surgery to receive either placebo or clonidine by a combination of oral and transdermal routes. Clonidine reduced enflurane requirements, intraoperative tachycardia, and myocardial ischaemia. Lastly, a relative "renal-sparing" effect was noted in CABG surgery patients who received clonidine, $4 \mu \mathrm{g} \cdot \mathrm{kg}^{-1}$, before induction. ${ }^{24}$

From these studies, it is apparent that $\alpha_{2}$ agonists are being used for more specific indications and by a variety of routes for its sympatholytic effect. The need to pre-empt sympathoexcitatory responses in sicker patients undergoing general anaesthesia will likely become an important indication for the clinical uses of this class of drugs.

\section{Regional anaesthesia}

Oral clonidine, 75-300 $\mu \mathrm{g}$, dose-dependently prolongs spinal anaesthesia with hyperbaric tetracaine in patients undergoing gynaecological and urological surgery. ${ }^{25}$ When compared with intrathecal fentanyl, oral clonidine $(200 \mu \mathrm{g})$, shortened the onset time of tetracaine sensory block and prolonged the duration of sensory and motor block. ${ }^{26}$ Although severe hypotension and/or bradycardia are slightly more likely to occur, postopera- tive opioid analgesic requirements are diminished. ${ }^{27}$ The onset time required to surgical anaesthesia is unaffected by clonidine but the duration of spinal and epidural anaesthesia was increased more than two-fold. ${ }^{28}$

From the data included in these studies, it is now possible to enhance, both qualitatively and quantitatively, conduction blockade with $\alpha_{2}$ agonists by various routes of administration. Unfortunately, we are still no closer to understanding the mechanism for these local anaesthetic enhancing qualities.

\section{General anaesthesia}

Although $\alpha_{2}$ agonists have been recognized to possess potent analgesic and sedative effects, these agents have not been used as sole anaesthetic agents. The combination of oral and transdermal clonidine (which maintained the plasma concentration of clonidine at therapeutic levels) provided lower anaesthetic requirements, greater haemodynamic stability, more rapid recovery from anaesthesia and less postoperative requirement for supplemental morphine for pain control in patients undergoing lower abdominal surgeries. ${ }^{29} \mathrm{An}$ issue which has been raised repeatedly is that $\alpha_{2}$ agonists may decrease the anaesthetic requirements not by a direct anaesthetic action but through their ability to alter the haemodynamic responses which are used to titrate the anaesthetic dose. Gabriel and his colleagues ${ }^{30}$ showed that in the presence of clonidine, the EEG spectral indices reflected a deeper anaesthetic state despite the fact the end-expiratory isoflurane concentration was reduced by $50 \%$. Preliminary results involving MAC studies in both volunteers and surgical patients support the contention that these agents have a primary anaesthetic action.

Clonidine, $4 \mu \mathrm{g} \cdot \mathrm{kg}^{-1} i v$, blocks the haemodynamic and catecholamine responses to laryngeal stimulation in patients undergoing coronary artery bypass graft surgery. ${ }^{31}$ Puig's group examined the effect of epidural clonidine on fentanyl requirements in patients undergoing general anaesthesia with a "nitrous-narcotic" technique for abdominal hysterectomy. ${ }^{32}$ Epidural clonidine decreased fentanyl requirements, improved cardiovascular stability, reduced pain intensity and the need for postoperative analgesia in the recovery room.

Data from these studies continue to stress the anaesthetic-sparing qualities of the $\alpha_{2}$ agonists in patients undergoing general anaesthesia. Whether the use of lower concentrations of the other anaesthetics will be associated with a better outcome is not addressed. However, it is anticipated that with lower doses of "fixed agents" faster emergence from general anaesthesia may be anticipated with a commensurate decrease in time in the post-anaesthesia care unit. 


\section{Postoperative pain}

In a study involving post-caesarean section patients, Capogna $e t a l .33$ showed a dose-dependent increase in the duration of epidural morphine/local anaesthetic analgesia when clonidine ( 75 or $150 \mu \mathrm{g}$ ) was included in the mixture. Also, the need for redosing was diminished in the patients who received clonidine. In a further study involving caesarean section patients the addition of either clonidine or epinephrine (which also activates $\alpha_{2}$ adrenergic receptors) to epidural sufentanil decreased the number of administrations of sufentanil by PCA. ${ }^{34}$

Patients undergoing gastrectomy with a combined general/epidural technique received epidural morphine with or without clonidine $\left(3 \mu \mathrm{g} \cdot \mathrm{kg}^{-1}\right)$ for postoperative analgesia. ${ }^{35}$ The cumulative number of supplemental systemic morphine injections via PCA was less in patients who had received clonidine each hour for $24 \mathrm{hr}$ after surgery $(P<0.05)$ while the VAS for pain was lower. In the clonidine-treated patients, sedation scores were higher, and mean blood pressures were lower.

Bernard's group ${ }^{36}$ compared the analgesic efficacy, arterial blood gases, and pharmacokinetic variables of an $i v$ infusion of fentanyl $75 \mu \mathrm{g} \cdot \mathrm{hr}^{-1}$ and a mixture of fentanyl $25 \mu \mathrm{g} \cdot \mathrm{hr}^{-1}$ plus clonidine $0.3 \mu \mathrm{g} \cdot \mathrm{hr}^{-1}$ after surgery. Pain relief, sedation, and supplemental ketoprofen requirements were similar in both groups. There were 106 episodes of arterial desaturation $(<90 \%$ for $>20 \mathrm{sec}$ ) in four of the patients in the fentanyl group compared with none in the clonidine-fentanyl group. Mean arterial blood pressure, plasma clearance, and the elimination rate constant of fentanyl were lower in the clonidine-fentanyl group than in the fentanyl group.

In an interesting study, Rockemann et al..$^{37}$ compared the analgesic effects of epidural clonidine $\left(8 \mu \mathrm{g} \cdot \mathrm{kg}^{-1}\right)$ alone, with a lower dose $\left(4 \mu \mathrm{g} \cdot \mathrm{kg}^{-1}\right)$ in combination with morphine $(2 \mathrm{mg})$, or morphine $\left(50 \mu \mathrm{g} \cdot \mathrm{kg}^{-1}\right)$ alone in patients undergoing pancreatectomy. Patients who received epidural solutions containing clonidine had an earlier onset and a longer duration of analgesia than when morphine alone was used. Haemodynamicaly, the clonidine-treated patients had a rate-depedent decrease in cardiac output.

Recently, it was demonstrated that the pre-operative administration of clonidine, $4 \mu \mathrm{g} \cdot \mathrm{kg}^{-1}$, decreased postoperative pain and analgesic requirements in a paediatric population. ${ }^{38}$ The efficacy of $\alpha_{2}$ agonists, alone, for postsurgical analgesia has yet to be shown in surgical patients other than in patients receiving quite high doses or in parturients. In other settings, the combination of $\alpha_{2}$ agonists with opioids appears to provide very durable analgesia with fewer side-effects than if either were used alone.

\section{Postoperative - miscellaneous}

Perioperative infusion of clonidine increases anabolic growth hormone levels ${ }^{39}$ and this may have a positive effect on nitrogen wasting. Mertes $e t$ al. ${ }^{40}$ demonstrated that nitrogen balance was well maintained in alcoholics undergoing radical cancer surgery when they were given clonidine perioperatively: an agematched (non-alcoholic) group of cancer surgery patients served as controls.

Treatment of uncontrolled shivering in patients in labour receiving epidural analgesia often consists of administration of meperidine. Mercadante et al. ${ }^{41}$ demonstrated that clonidine $(0.15 \mathrm{mg} i \mathrm{v})$ was as effective as the standard therapy for shivering during labour. In a large double-blind study the prophylactic use of clonidine, $4 \mu \mathrm{g} \cdot \mathrm{kg}^{-1}$, iv, immediately after induction of general anaesthesia, reduced the incidence, severity and duration of postoperative shivering without changing the incidence of sedation. ${ }^{42}$

The use of $\alpha_{2}$ agonists in the immediate emergence and early postoperative period appears to hold out great promise. This class of compound may represent the first of its kind to provide such a positive effect on nitrogen balance. If this is corroborated, the utility of $\alpha_{2}$ agonists in the severely ill intensive care unit patient may become de rigeur.

\section{Chronic pain}

In an "enrichment" study design, transdermal clonidine could decreased pain in subjects with diabetic neuropathy. ${ }^{43}$ Since phentolamine was ineffective, even in the most responsive patients, the mechanism for the clonidine response appears to be separate from its sympatholytic action. Anecdotally, it has been noted in a patient suffering from pharyngeal cancer pain, that the addition of clonidine to intracerebroventricular doses of morphine enhanced the efficacy of the opioid. ${ }^{44}$ Similarly, in a patient suffering from intractable pain following spinal cord injury, the addition of clonidine resulted in rapid improvement. ${ }^{45}$

While these studies continue to hold out hope, the full potential of $\alpha_{2}$ agonists for chronic pain states has not been rigorously tested. What is needed are studies that demonstrate that the analgesic effects are durable and without long-term complications.

\section{Complications}

An extension of the pharmacological properties of $\alpha_{2}$ agonists is the development of bradycardia and hypotension. ${ }^{5,46,47}$ Bradycardia can be pre-empted by 
the prophylactic use of an anticholinergic agent (atropine or glycopyrrolate) although the increment in heart rate which can occur in response to anticholinergics is reduced in both adults and children. ${ }^{48}$ Conversely, hypotension responds in an exaggerated fashion to treatment with ephedrine. ${ }^{49}$ The pressor response to phenylephrine is enhanced following oral clonidine and, thus, restoration of blood pressure can be achieved effectively by either ephedrine or phenylephrine. ${ }^{50}$

\section{Conclusion}

The use of $\alpha_{2}$ agonists, either alone or in combination, is becoming widespread in anaesthesia. The original enthusiasm for this class of compound for its plethora of beneficial effects appears to have been justified based on the more recent clinical studies reported here. In the next decade, the field will continue to evolve with the clinical introduction of the second generation of $\alpha_{2}$ agonists, notably dexmedetomidine which is a more selective, specific and efficacious compound than the prototype, clonidine. Furthermore, formulations allowing several different routes of administration, ranging from transdermal to neuraxial, will further extend its clinical utility.

\section{Acknowledgements}

The authors gratefully acknowledge the support of the Uehara Foundation (T.K.), the National Institutes of Health (M.M.) and the Department of Veterans Affairs (M.M.).

\section{References}

1 Ablquist PR. A study of the adrenotropic receptors. Am J Physiol 1948; 153: 586-600.

2 Bylund DB, UPritchard DC. Characterization of alpha- 1 and alpha-2 adrenergic receptors. Int Rev Neurobiol 1983; 24: 343-431.

3 Toon S, Hopkins KJ, Aarons L, Rowland M. Rate and extent of absorption of clonidine from a transdermal therapeutic system. J Pharm Pharmacol 1989; 41: 17-21.

4 Cunningham FE, Baughman VL, Peters J, Laurito $C E$. Comparative pharmacokinetics of oral versus sublingual clonidine. J Clin Anesth 1994; 6: 430-3.

5 Lonnquist PA, Bergendabl HTG, Eksborg $S$. Pharmacokinetics of clonidine after rectal administration in children. Anesthesiology 1994; 81: 1097-101.

6 Scheinin H, Virtanen $R$, MacDonald E, Lammintausta $R$, Scheinin $M$. Medetomidine - a novel alpha 2adrenoceptor agonist: a review of its pharmacodynamic effects. Prog Neuropsychopharmacol Biol Psychiatry 1989; 13: 635-51.

7 Dyck JB, Maze $M$, Haack C, Vuorilebto L, Shafer SL. The pharmacokinetics and hemodynamic effects of intra- venous and intramuscular dexmedetomidine hydrochloride in adult human volunteers. Anesthesiology 1993; 78: 813-20.

8 Ernsberger P, Meeley MP, Mann J], Reis DJ. Clonidine binds to imidazole binding sites as well as alpha 2 -adrenoceptors in the ventrolateral medulla. Eur J Pharmacol 1987; 134: 1-13.

9 Zonnenchein $R$, Diamant $S$, Atlas D. Imidazoline receptors in rat liver cells: a novel receptor or a subtype of alpha 2-adrenoceptors? Eur J Pharmacol 1990; 190 : 203-15.

10 Tibirica E, Feldman J, Mermet D, Gonon F, Bousquet $P$. A imidazoline-specific mechanism for the hypotensive effect of clonidine: a study with yohimbine and idazoxan. J Pharmacol Exp Ther 1991; 256: 606-13.

11 Miettunen TJ, Kanto JH, Salonen $M A$, Scheinin $M$. The sedative and sympatholytic effects of oral tizanidine in healthy volunteers. Anesth Analg 1996; 82: 817-20.

12 Noyer $M$, de Laveleye $F$, Vauquelin $G$, Gobert $J$, Wulfert $E$. Mivazerol, a novel compound with high specificity for alpha 2 adrenergic receptors: binding studies on different human and rat membrane preparations. Neurochemistry International, 1994; 24: 221-9.

13 Takabashi $H$, Nishikawa T. Oral clonidine does not alter vecuronium neuromuscular blockade in anaesthetized patients. Can J Anaesth 1995; 42: 511-5.

14 Filos KS, Patroni O, Goudas LC, Bosas $O$, Kassarans $A$, Gartaganis $S$. A dose-response study of orally administered clonidine as premedication in the elderly: evaluating hemodynamic safety. Anesth Analg 1993; 77 : 1185-92.

15 Mikawa K, Maekawa N, Nishina K, Takao Y, Yaku H, Obara $H$. Efficacy of oral clonidine premedication in children. Anesthesiology 1993; 79: 926-31.

16 Ghignone $M$, Noe $C$, Calvillo $O$, Quintin L. Anesthesia for ophthalmic surgery in the elderly: the effects of clonidine on intraocular pressure, perioperative hemodynamics, and anesthesia requirement. Anesthesiology 1988; 68: 707-16.

17 Kumar A, Bose S, Bhattacharya A, Tandon OP, Kundra $P$. Oral clonidine premedication for elderly patients undergoing intraocular surgery. Acta Anaesthesiol Scand 1992; 36: 159-64.

18 Devcic A, Muzi $M$, Ebert TJ. The effects of clonidine on desflurane-mediated sympathoexcitation in humans. Anesth Analg 1995; 80: 773-9.

19 Weiskopf RB, Eger EI II, Noorani M, Daniel $M$. Fentanyl, esmolol, and clonidine blunt the transient cardiovascular stimulation induced by desflurane in humans. Anesthesiology 1994; 81: 1350-5.

20 Tanaka $M$, Nishikawa $T$. Oral clonidine premedication attenuates the hypertensive response to ketamine. $\mathrm{Br} \mathrm{J}$ Anaesth 1994; 73: 758-62. 
21 Tanaka S, Tsucbida $H$, Namba $H$, Namiki A. Clonidine and lidocaine inhibition of isoflurane-induced tachycardia in humans. Anesthesiology 1994; 81: 1341-9.

22 Howie $M B$, Hiestand DC, Jopling $M W$, Romanelli VA, Kelly WB, McSweeney TD. Effect of oral clonidine premedication on anesthetic requirement, hormonal response, hemodynamics, and recovery in coronary artery bypass graft surgery patients. J Clin Anesth 1996; 8: 263-72.

23 Ellis JE, Drijvers G, Pedlow $S$, et al. Premedication with oral and transdermal clonidine provides safe and efficacious postoperative sympatholysis. Anesth Analg 1994; 79: 1133-40.

$24 K u l k a$ PJ, Tryba $M$, Zenz $M$. Preoperative alpha2adrenergic receptor agonists prevent the deterioration of renal function after cardiac surgery: results of a randomized, controlled trial. Crit Care Med 1996; 24 : 947-52.

25 Ota K, Namiki A, Iwasaki H, Takabashi I. Dose-related prolongation of tetracaine spinal anesthesia by oral clonidine in humans. Anesth Analg 1994; 79: 1121-5.

26 Singh H, Liu J, Gaines GY, White PF. Effect of oral clonidine and intrathecal fentanyl on tetracaine spinal block. Anesth Analg 1994; 79: 1113-6.

27 Niemi $L$. Effects of intrathecal clonidine on duration of bupivacaine spinal anaesthesia, haemodynamics, and postoperative analgesia in patients undergoing knee arthroscopy. Acta Anaesthesiol Scand 1994; 38: 724-8.

28 Klimscha W, Chiari A, Krafft $P$, et al. Hemodynamic and analgesic effects of clonidine added repetitively to continuous epidural and spinal blocks. Anesth Analg 1995; 80: 322-7.

29 Segal IS, Javis DJ, Duncan SR, White PF, Maze M. Clinical efficacy of oral-transdermal clonidine combinations during the perioperative period. Anesthesiology 1991; 74: 220-5.

30 Gabriel AH, Faryniak B, Sojka G, Czech T, Freye E, Spiss $C K$. Clonidine: an adjunct in isoflurane $\mathrm{N} 2 \mathrm{O} / \mathrm{O} 2$ relaxant anaesthesia. Effects on EEG power spectra, somatosensory and auditory evoked potentials. Anaesthesia 1995; 50: 290-6.

31 Kulka PJ, Tryba M, Zenz M. Dose-response effects of intravenous clonidine on stress response during induction of anesthesia in coronary artery bypass graft patients. Anesth Analg 1995; 80: 263-8.

32 Murga G, Samso E, Valles J, Casanovas P, Puig MM. The effect of clonidine on intra-operative requirements of fentanyl during combined epidural/general anaesthesia. Anaesthesia 1994; 49: 999-1002.

33 Capogna $G$, Celleno $D$, Zangrillo A, Costantino $P$, Foresta $S$. Addition of clonidine to epidural morphine enhances postoperative analgesia after cesarean delivery. Reg Anesth 1995; 20: 57-61.
34 Vercauteren MP, Vandeput DM, Meert TF, Adriaensen $H A$. Patient-controlled epidural analgesia with sufentanil following Caesarean section: the effect of adrenaline and clonidine admixture. Anaesthesia 1994; 49: 767-71.

35 Anzai $\Upsilon$, Nishikawa $T$. Thoracic epidural clonidine and morphine for postoperative pain relief. Can J Anaesth $1995 ; 42: 292-7$.

36 Bernard JM, Lagarde $D$, Souron $R$. Balanced postoperative analgesia: effect of intravenous clonidine on blood gases and pharmacokinetics of intravenous fentanyl. Anesth Analg 1994; 79: 1126-32.

37 Rockemann $M G$, Seeling $W$, Brinkmann $A$, et al. Analgesic and hemodynamic effects of epidural clonidine, clonidine/morphine, and morphine after pancreatic surgery - a double-blind study. Anesth Analg $1995 ; 80: 869-74$.

38 Mikawa K, Nishina K, Maekawa N, Obara $H$. Oral clonidine premedication reduces postoperative pain in children. Anesth Analg 1996; 82: 225-30.

39 De Kock M, Merello L, Pendeville P, Maiter D, Scholtes $J L$. Effects of intravenous clonidine on the secretion of growth hormone in the perioperative period. Acta Anaesthesiol Belg 1994; 45: 167-74.

40 Mertes $N$, Goeters $C$, Kubmann $M$, Zander JF. Postoperative alpha 2-adrenergic stimulation attenuates protein catabolism. Anesth Analg 1996; 82: 258-63.

41 Mercadante S, De Michele $P$, Letterio G, Pignataro A, Sapio $M$, Villari $P$. Effect of clonidine on postpartum shivering after epidural analgesia: a randomized, controlled, double-blind study. J Pain Symptom Manage 1994; 9: 294-7.

42 Vanderstappen $I$, Vandermeersch $E$, Vanacker $B$, Mattbeussen $M$, Heriggers $P$, Van Aken $H$. The effect of prophylactic clonidine on postoperative shivering. A large prospective double-blind study. Anaesthesia 1996; 51: 351-5.

43 Byas-Smith $M G$, Max MB, Muir J, Kingman A. Transdermal clonidine compared to placebo in painful diabetic neuropathy using a two-stage 'enriched enrollment' design. Pain 1995; 60: 267-74.

44 Loriferne JF, Souchal Delacour I, Rostaing S, N'Guyen $J P$, Bonnet $F$. Combined intraventricular morphine and clonidine administration for cephalic cancer pain relief. (French) Ann Fr Anesth Reanim 1995; 14: 233-6.

45 Siddall PJ, Gray M, Rutkowski S, Cousins MJ. Intrathecal morphine and clonidine in the management of spinal cord injury pain: a case report. Pain 1994; 59: 147-8.

46 Carabine UA, Wright PMC, Moore J. Preanaesthetic medication with clonidine: a dose-response study. $\mathrm{Br} \mathrm{J}$ Anaesth 1991; 67: 79-83.

47 Aantaa $R$, Kanto J, Scheinin $M$. Intramuscular dexmedetomidine, a novel alpha 2 -adrenoceptor agonist, 
as premedication for minor gynaecological surgery. Acta Anaesthesiol Scand 1991; 35: 283-8.

48 Nishikawa $T$, Dobi S. Oral clonidine blunts the heart rate response to intravenous atropine in humans. Anesthesiology 1991; 75: 217-22.

49 Nishikawa $T$, Kimura T, Taguchi N, Dobi S. Oral clonidine preanesthetic medication augments the pressor responses to intravenous ephedrine in awake or anesthetized patients. Anesthesiology 1991; 74: 705-10.

50 Inomata $S$, Nishikawa $T$, Kibara $S$, Akiyoshi $\Upsilon$.

Enhancement of pressor response to intravenous phenylephrine following oral clonidine medication in awake and anaesthetized patients. Can J Anaesth 1995; 42: 119-25. 
Takahiko Kamibayashi $\mathrm{MD}$, Katsumi Harasawa MD, Mervyn Maze MB CHB MRCP

\section{Les agonistes alpha-2 adrénergiques}

dine a le même profil pharmacocinétique et pharmacodynamique. ${ }^{4} \mathrm{La}$ voic sublinguale peut donc être utilisée efficacement chez les patients à jeun, ceux qui ont de la difficulté à avaler ou ceux qui sont incapables d'absorber des médicaments par le tractus gastrointestinal. La clonidine est maintenant utilisée par voie rectale chez les enfants avec une biodisponibilité de $95 \%$ et des variables pharmacocinétique inchangées. ${ }^{5}$

La médétomidine, 4(5)-1-1,3-diméthylphény([éthyl] imidazole) représente le prototype des nouveaux agonistes hypersélectifs $\alpha_{2}$. Elle est plus sélective que la clonidine et un agoniste complet de cette classe de récepteurs. ${ }^{6} \mathrm{La}$ médétomidine est extrêmement puissante et active à de faibles concentrations nanomolaires; elle a été abondamment utilisée en pratique vétérinaire en Europe. Comme le D-énantionère de ce racémate constitue l'ingrédient actif, c'est la dexmédétomidine qui a été développée pour usage clinique. La dexmédétomidine a un profil pharmacocinétique plus favorable à l'utilisation périopératoire que la clonidine parce que sa demi-vie est plus courte d'environ deux heures. ${ }^{7}$ Des études de Phase III sur ce produit sont présentement en cours en Amérique du Nord, en Europe et au Japon pour rechercher s'il a des avantages à la période périopératoire.

Quelques-uns des ligands ont un anneau imidazole qui favorise sa liaison avec des récepteurs non adrénergiques à affinité préférentielle pour l'imidazole ${ }^{8,9}$ aussi bien qu'avec des adrénorécepteurs $\alpha_{2}$. Les propriétés cardio-vasculaires des ligands $\alpha_{2}$ peuvent varier considérablement si le récepteur à affinité préférentielle imidazole est aussi activé. ${ }^{11}$ Les autres composés imidazole étudiés pour leurs propriétés agonistes $\alpha_{2}$ sont la tizanidine et le mivazérol. ${ }^{12}$

\section{Prémédication}

Parce qu'ils ont des propriétés sédatives, anxiolytiques et antisialogènes, les agonistes $\alpha_{2}$ possèdent les attributs d'une bonne prémédication. En outre, les agonistes $\alpha_{2}$ en prémédication potentialisent l'action des anesthésiques et diminuent les besoins en anesthésie pendant la chirurgie. Cet effet est observé universellement quel que soit le type d'anesthésique, intraveineux, volatil ou local. À l'inverse, les besoins en relaxant neuromusculaire ne sont pas affectés par un prétraitement aux agonistes $\alpha_{2}{ }^{13}$ 
L'efficacité de l'administration des agonistes $\alpha_{2}$ à des patients qui se situent aux extrêmes de l'âge est maintenant établie. ${ }^{14,15}$ Les personnes âgées semblent être ceux qui sont les plus susceptibles de bénéficier de l'action sympatholytique du produit à cause de la prévalence d'insuffisance coronaire et d'hypertension chez eux. ${ }^{16,17}$ Chez des patients âgés de 4-12 ans, la combinaison de $4 \mathrm{mg} \cdot \mathrm{kg}^{-1}$ de clonidine et de 30 $\mathrm{mg} \cdot \mathrm{kg}^{-1}$ d'atropine par la voie orale 105 minutes avant leur arrivé en salle d'opération a été plus efficace que le diazépam pour procurer l'anxiolyse et la sédation. ${ }^{15}$

La clonidine a atténué considérablement l'augmentation rapide de la pression artérielle et de la fréquence cardiaque pendant la transition entre faibles et hautes concentrations de desflurane. ${ }^{18,19}$ De façon identique, la réponse sympathicoexcitatrice à $1,0 \mathrm{mg} \cdot \mathrm{kg}^{-1}$ de kétamine intraveineuse a été réduite par $5 \mu \mathrm{g} \cdot \mathrm{kg}^{-1} \mathrm{de}$ clonidine per os comme le montrait une augmentation moins marquée de la pression artérielle. ${ }^{20}$ La prémédication à la clonidine atténuait l'hypertension, la tachycardie aussi bien que l'augmentation progressive de la catécholamine plasmatique lorsqu'on augmentait par paliers la concentration de l'isoflurane pendant l'anesthésie au masque. ${ }^{21}$

Plusieurs études récentes ont rapporté l'utilisation de la clonidine en prémédication chez des insuffisants coronariens hospitalisés. La clonidine $5 \mu \mathrm{g} \cdot \mathrm{kg}^{-1}$ diminuait le besoin de sufentanil peropératoire et la réponse des catécholamines tout en maintenant une bonne stabilité hémodynamique pendant la chirurgie de revascularisation myocardique. ${ }^{22}$ Pour déterminer si l'ajout de clonidine à une anesthésie générale standard pouvait procurer une sympathicolyse postopératoire efficace à l'insuffisant coronarien coronaire connu ou suspecté, Ellis et al..$^{23}$ ont réparti aléatoirement des patients soumis à une chirurgie non cardiaque majeure et non urgente pour recevoir soit un placebo soit la clonidine dans une combinaison de voies orale et transdermique. La clonidine a diminué le besoin en enflurane, la tachycardie peropératoire et l'ischémie myocardique. Finalement, un effet d'épargne rénal relatif a été noté pendant le pontage coronaire chez des patients qui recevaient de la clonidine $4 \mu \mathrm{g} \cdot \mathrm{kg}^{-1}$ avant l'induction. ${ }^{24}$

À partir de ces études, on peut constater maintenant que les agonistes $\alpha_{2}$ sont utilisés par différentes voies d'administration pour des indications plus spécifiques et pour leur activité sympathicolytique. La nécessité de prévenir les réponses sympathicoexcitatoires chez les grands malades sous anesthésie générale deviendra vraisemblablement une indication importante de cette catégorie de médicaments.

\section{Anesthésie régionale}

Chez des patient(e)s soumis(es) à une chirurgie gynécologique ou urologique, la clonidine orale $(75-300 \mu \mathrm{g})$ prolonge l'anesthésie rachidienne à la tétracaïne hyperbare proportionnellement à la dose. ${ }^{25}$ Comparée au fentanyl sous-arachnoïdien, la clonidine orale $(200 \mu \mathrm{g})$ a réduit la période de latence du bloc sensitif à la tétracaïne et prolongé la durée du bloc sensitif et moteur. ${ }^{26}$ Malgré la possibilité un peu plus élevée d'hypotension importante et de bradycardie, les besoins en morphinique pour analgésie postopératoire ont diminué. ${ }^{27} \mathrm{La}$ période de latence précédant l'anesthésie chirurgicale n'était pas affectée par la clonidine mais la durée de l'anesthésie rachidienne et péridurale doublait. ${ }^{28}$

À partir des données obtenues dans ces études, il est maintenant possible d'améliorer l'anesthésie régionale avec des agonistes $\alpha_{2}$ administrés par différentes voies. Malheureusement, nous ne connaissons pas encore le mécanisme de cette action.

\section{Anesthésie générale}

Malgré leurs propriétés analgésiques et sédatives reconnues, les agonistes $\alpha_{2}$ ne sont pas utilisés seuls pour produire l'anesthésie. La combinaison orale et transdermique de clonidine (qui permet de maintenir la concentration plasmatique de clonidine à des niveaux thérapeutiques) a diminué le besoin d'anesthésique, procuré une plus grande stabilité hémodynamique, un réveil plus rapide et a diminué le besoin postopératoire de morphine supplémentaire chez des patients soumis à des interventions abdominales basses. ${ }^{29}$ On s'est souvent demandé s'il était possible que les agonistes $\alpha_{2}$ ne diminuent pas les besoins anesthésiques par une action anesthésique directe mais plutôt par leur capacité de modifier les réactions hémodynamiques qui sont utilisées pour évaluer l'effet de la concentration anesthésique. Gabriel $e t a l^{30}$ ont montré qu'en présence de clonidine, l'analyse spectrale de ÉEG reflétait une anesthésie plus profonde malgré une réduction de la concentration télé-expiratoire d'isoflurane de $50 \%$. Des études préliminaires sur le MAC réalisées à la fois chez des volontaires et chez des patients supportent l'hypothèse selon laquelle ces agents exercent une action anesthésique directe.

La clonidine $\left(4 \mu \mathrm{g} \cdot \mathrm{kg}^{-1} i . p\right)$ bloque les réponses hémodynamiques et la libération de catécholamines provoquées par la stimulation laryngée chez des patients soumis à une chirurgie de revascularisation myocardique. ${ }^{31}$ Le groupe de Puig a étudié l'influence de la clonidine péridurale sur les besoins en fentanyl de patientes sous anesthésie générale au prototype d'azote/morphinique opérées pour une hystérectomie abdominale. La clonidine péridurale a diminué les besoins de fentanyl, amélioré la stabilité cardio-vasculaire, 
diminué l'intensité de la douleur et le besoin d'analgésie postopératoire à la salle de réveil

Les données fournies par ces études mettent en lumière les qualités d'épargne anesthésique des agonistes $\alpha_{2}$ chez les patients soumis à une anesthésie générale. On n'a toutefois pas étudié si le fait qu'ils soient combinés à des concentrations plus faibles d'anesthésiques est associé à de meilleurs résultats. Cependant, on anticipe qu'avec des concentrations moins élevées d'un agent donné, le patient se réveillera plus rapidement et séjournera moins longtemps à l'unité de soins postanesthésiques.

\section{Douleur postopératoire}

Après la césarienne, Capogna $e t a l .{ }^{33}$ ont constaté une augmentation dose dépendante de la durée de l'analgésic péridurale morphine/anesthésique local quand la clonidine $(75-150 \mu \mathrm{g})$ était ajoutée au mélange. La clonidine diminuait aussi la nécessité de réajuster les doses. Au cours d'une étude ultérieure réalisée chez des accouchées par césarienne, l'ajout de clonidine ou d'épinéphrine (qui active aussi les récepteurs $\alpha_{2}$-adrénergique) au sufentanil péridural a diminué le nombre des injections de sufentanil par PCA. ${ }^{34}$

Des gastrectomisé sous anesthésie générale combinée à une péridurale ont reçu de la morphine péridurale avec ou sans clonidine $\left(3 \mu \mathrm{g} \cdot \mathrm{kg}^{-1}\right)$ pour l'analgésic postopératoire. ${ }^{35}$ Les patients qui avaient reçu la clonidine à toutes les heures pendant 24 heures après la chirurgie recevaient moins d'injections supplémentaires de morphine par PCA $(P<0,05)$ alors que leur score sur l'EVA de la douleur était inférieur.

Le groupe de Bernard ${ }^{36}$ a comparé l'efficacité analgésique, la gazométrie et les variables pharmacocinétiques d'une perfusion intraveineuse de fentanyl $75 \mu \mathrm{g} \cdot \mathrm{h}^{-1}$ avec un mélange de fentanyl de $25 \mu \mathrm{g} \cdot \mathrm{h}^{-1}$ et de clonidine $0,3 \mu \mathrm{g} \cdot \mathrm{h}^{-1}$ après la chirurgie. Le soulagement de la douleur, la sédation et les besoins supplémentaires de kétoprofen étaient identiques dans les deux groupes. Il y a eu 106 épisodes de désaturation artérielle $(<90 \%$ pour $>20 \mathrm{sec}$ ) chez quatre des patients dans le groupe fentanyl comparé avec aucun dans le groupe clonidine-fentanyl. La pression artérielle moyenne, la clairance plasmatique et la constante d'élimination du fentanyl étaient inférieures dans le groupe clonidine-fentanyl à celles du groupe fentanyl.

Dans d'une étude intéressante, Rockemann et al. ${ }^{37}$ ont comparé les effets analgésiques de l'épidurale à la clonidine $\left(8 \mu \mathrm{g} \cdot \mathrm{kg}^{-1}\right)$ seule avec une dose inférieure $\left(4 \mu \mathrm{g} \cdot \mathrm{kg}^{-1}\right)$ associée à la morphine $(2 \mathrm{mg})$ ou à la morphine $\left(50 \mu \mathrm{g} \cdot \mathrm{kg}^{-1}\right)$ seule chez des patients soumis à une pancréatectomie. Les patients qui recevaient les solutions péridurales contenant de la clonidine avaient une analgésie qui débutait plus tôt et durait plus longtemps que lorsque la morphine seule était utilisée. Du point de vue hémodynamique, la clonidine produisait une baisse du débit cardiaque proportionnelle à la baisse de la fréquence.

Récemment, on a démontré que l'administration préopératoire de clonidine $\left(4 \mu \mathrm{g} \cdot \mathrm{kg}^{-1)}\right.$ diminuait la douleur postopératoire et les besoins analgésiques chez les enfants. ${ }^{38}$ L'efficacité des agonistes $\alpha_{2}$ seuls administrés pour l'analgésie postopératoire n'a pas été démontrée chez des patients qui en recevaient de très hautes doses ainsi que chez des parturientes. Sous d'autres conditions, la combinaison d'agonistes $\alpha_{2} /$ morphinique semble procurer une analgésie très durable avec moins d'effets secondaires que chacun des deux produits utilisé séparément.

\section{Effets postopératoires divers}

Une perfusion périopératoire de clonidine augmente la concentration de l'hormone anabolique de croissance ${ }^{39}$ et ceci peut avoir un effet positif sur la déperdition azotée. Mertes et al..$^{40}$ ont démontré que l'équilibre azoté se maintenait chez des alcooliques opérés pour une chirurgie radicale néoplasique quand on leur administrait de la clonidine périopératoire: un groupe apparié pour l'âge (cancéreux non alcooliques) servait de contrôle.

Pour traiter les frissons chez les parturientes pendant le travail sous analgésie péridurale, on administre souvent de la mépéridine. Mercadante $e t a l l^{41}$ ont démontré que la clonidine $(0,15 \mathrm{mg} i v)$ était aussi efficace que le traitement standard pendant le travail. Une vaste étude prospective à double insu sur l'usage prophylactique de la clonidine $\left(4 \mu \mathrm{g} \cdot \mathrm{kg}^{-1} i v\right)$ administrée immédiatement après l'induction de l'anesthésie générale a montré qu'elle réduisait l'incidence, la gravité et la durée du frissonnement postopératoire sans modifier la sédation. ${ }^{42}$

L'utilisation d'agonistes $\alpha_{2}$ en urgence et à la période postopératoire immédiate est pleine de promesses. Ces produits semblent avoir un effet favorable unique sur l'équilibre azoté. S'il est corroboré, l'emploi des agonistes $\alpha_{2}$ deviendra la règle chez des patients en phase critique à l'unité de soins intensifs.

\section{Douleur chronique}

Une étude a montré que la clonidine transdermique pouvait diminuer la douleur chez des sujets atteints de neuropathie diabétique. ${ }^{43}$ Comme la phentolamine était inefficace même chez les patients les plus aptes à répondre à ce traitement, le mécanisme de la réponse à la clonidine semble indépendant de son activité sympathicolytique. De façon anecdotique, on a observé chez 
un patient souffrant d'une pharyngodynie d'origine cancéreuse que l'ajout de clonidine aux doses ventriculaires intracérébrales de morphine augmentait l'efficacité de ce morphinique. ${ }^{44}$ Identiquement, l'addition de clonidine a soulagé rapidement un patient souffrant de douleur réfractaire à la suite d'une lésion médullaire. ${ }^{45}$

Même si ces études sont prometteuses, le plein potentiel des agonistes $\alpha_{2}$ pour le traitement des états douloureux chroniques n'a pas été ćvalué rigoureusement. Nous avons besoin d'études qui démontrent que les effets analgésiques sont durables et, à long terme, sans complications.

\section{Complications}

La bradycardie et l'hypotension représentent la suite logique des propriétés pharmacologiques des agonistes $\alpha_{2}{ }^{3,46,47}$ On peut prévenir la bradycardie par l'administration préalable d'un agent anticholinergique (l'atropine ou le glycopyrrolate) quoique l'augmentation de la fréquence cardiaque qui peut survenir en réponse aux anticholinergiques est diminuée à la fois chez les adultes et chez les enfants. ${ }^{48} \mathrm{Au}$ contraire, l'hypotension répond de façon exagérée à l'administration d'éphédrine. ${ }^{49} \mathrm{La}$ réponse vasopressive à la phényléphrine est exagérée après l'administration de clonidine orale et on peut donc ainsi rétablir la pression artérielle efficacement avec soit l'éphédrine soit la phényléphrine. ${ }^{50}$

\section{Conclusion}

En anesthésie, l'utilisation des agonistes $\alpha_{2}$, seuls ou en association se répand rapidement. En vertu des nombreux avantages que les agonistes $\alpha_{2}$ procurent, l'enthousiasme initial démontré envers cette classe de composés semble justifié sur la base des plus récentes études cliniques que nous avons rapportées. La prochaine décennie verra se continuer cette évolution avec l'introduction en clinique de la deuxième génération des agonistes $\alpha_{2}$, en particulier de la dexmédétomidine qui est plus sélective, plus spécifique et plus efficace que son prototype, la clonodine. En outre, les cliniciens trouveront d'autres indications pour ces produits grâce à des préparations adaptées aux différents modes d'administration, de la voie transdermique à celle du système nerveux central.

\section{Références}

(Voir page Rl6) 